\title{
All Creation Groans: Toward a Theology of Disease and Global Health, edited by Daniel W. O'Neill and Beth Snodderly, Pickwick 2021
}

\author{
William Newbrander ${ }^{a}$
}

${ }^{a} \mathrm{MHA}, \mathrm{MAE}, \mathrm{PhD}$, International Public Health \& Health Economics Consultant, USA

\section{Introduction}

Of the many problems of this world, pandemics and disease are a major cause of humankind's misery. This fact is highlighted by the current COVID-19 pandemic and the death and destruction it has inflicted on the world across all populations and countries. The common approach of the global health community has been to focus on science and medicine to deal with the corrupted creation that has been afflicted with disease and its many ramifications on the human body. Disease impacts individuals, families, and communities, not just physically, but also spiritually, socially, psychologically, and ecologically. The effects are felt on an individual and collective basis. In seeking solutions, the global health community has often been blind to spiritual elements having any relevance in identifying root causes. Our hope, as Christians in a fallen world, rests in God having every intention of healing this world from the ill forces brought about by evil through redemption, both spiritual and physical.

The absence of solutions presents an opportunity and obligation for the church and Christians to be involved in alleviating disease and promoting health, as God intended. But we need a new theological element to our perspective in order to see how fighting disease and promoting health is part of our spiritual responsibility in carrying out God's plans for reclaiming all of creation. This challenge is not intended as a guilt-laden obligation for Christians in global health, but rather, it is as an opportunity to partner with God, other Christians, and the church in redeeming and reclaiming the creation, including man, to what God wills and what He will bring about in the "new earth" to come. To this end, the book "All Creation Groans: Toward a Theology of Disease and Global Health" makes a wonderful contribution to addressing our wellknown global health issues by seeking out solutions with an inclusive theological element. Its editors, O'Neill and Snodderly, state: "There is an increasing call in the Christian community to promote global health, as an indispensable part of glorifying God, by thoughtful application of evidence-based and biblically-based approaches for new levels of innovation and service...."(p. xxvii).

\section{Summary}

The metanarrative of the book provides the grounds for a deeper, thoughtful re-enunciation by Christians of a missiological agenda to bring healing and wholeness to those afflicted by disease. The book is quite ambitious in addressing the issue of Christians' active involvement in lessening and reversing the mayhem caused by disease and suffering in God's creation from a variety of perspectives: theological, scientific, medical research, philosophical, historical, and regional. This is accomplished by tapping an impressive array 
of 16 experts to pen the 19 chapters, as well as the Introduction and Epilogue. The authors are physicians and health care workers, theologians, scientists, researchers, public health specialists, seminary professors, missiologists, and pastors, many with practical global health experience. The result is an assortment of traditions and perspectives on the origin of evil, sources of disease, and the responsibility of believers and the Church to be a part of God's greater plan to alleviate disease and promote health.

Foundational to many of the views expressed in this book is the influence of Ralph Winter, a missionary, missiologist, mission strategist who was an advocate to shift the church's great commission focus from observing political borders to emphasizing people groups across such boundaries, especially those people groups which were unreached. He died in 2009, but prior to that sought to shake up the church's theology of disease by getting it to focus on eliminating disease, not just alleviating its impact on individuals and their communities. He was one of the first evangelicals to posit the need for the church to not only evangelize the world, but to fight disease: "to awaken, energize, and nourish the Christian imagination to include a new form of service to bring glory to God by exploring and conquering the roots of diseases."'(p. xxx). Hence, O'Neill and Snodderly state in the Introduction, "Once we acknowledge disease in the category of "evil," we can see the need to mobilize the body of Christ to seek to fight disease at its origins as a means of anticipating "God's eventual world."(p. xxx). Yet, the areas examined are not done in a simplistic manner but recognize the multiple determinants of health: physical, social, psychological, and environmental. Fundamental to it all is an emphasis on the underlying spiritual dimensions.

The book provides a solid background of theology and discusses on the origins of evil in the universe and beginning with a review of the historical theological perspectives of disease through the ages.

Dec 2021. Christian Journal for Global Health 8(2)
The chapters introduce a wide range of perspectives on aspects of theology with respect to evil, disease, and its origins in order that there be no "blind spots" in the case put forward by the book. These chapters on theology include:

- Historical, Contemporary and Globalized Theologies of Disease (Ch. 1),

- The Biblical Context for a Theology of Disease (2),

- A Theology of Creation: Order Out of Chaos (3),

- Early Church Perspectives on the Cosmic Conflict (4),

- A Theology of Health for the Nations (6),

- A Theology of Ecology: Earth Care and Health (7),

- A Theology of Love in the First Epistle of John (8).

These are helpful in providing a full complement of theological perspectives on disease, evil, God's plan for "the new earth," and the Christian's response and role in being an instrument of God's grand designs.

The book then moves on to provide chapters on our response to disease based upon various perspectives (evangelical, Pentecostal tradition, West Africa, East Africa) and disciplines (anthropology, scientist, medical researchers, public health, and missiology). One of the strengths of the book is that it is intended not only for physicians and scientists but a wider audience focused on global health issues. So, the editors include a chapter that is a tutorial: "A Scientist's Perspective on Disease and Death" by biochemical geneticist Richard Gunasekera is a useful introduction for nonscientists to basic genetics, genetic diseases, infections from bacteria and viruses, technologies dealing with disease, including nanotechnologies to eradicate pathogens, and Satan's role in disease. This is helpful in understanding disease and its source from a scientific and spiritual perspective for all of us who are not research scientists. Gunasekera concludes "Hence, the causality of genetic diseases 
(from inherited genes or from random mutations) or from infectious agents such as retroviruses which insert their DNA into the very genome of other organisms, causing suffering, pain, and death, could be, in turn, attributed to the "works of the devil.'"(p. 170)

The final two chapters, 18 and 19, by Gregory Boyd of Woodland Hills Church, provide a case for the chaos and disease seen in this world as being a result of Satan's efforts. The tares of Matthew 13:24-30 include disease being sown by evil spiritagents to disrupt God's creation. For those who doubt that disease was a corruption of nature, Chapter 19 provides responses to five objections to the corruption of nature hypothesis. Boyd strongly states the need to recapture the original purposes of God for creation by destroying the works of the devil, including disease.

In the Epilogue, O'Neill provides a series of eleven responses and solutions to the situation and how global health efforts can be part of the solution.

\section{Review}

The editors and various authors of this book lay out a clear challenge for the church: to eradicate disease, as Ralph Winter and Dan Fountain laid the foundation for meeting that goal as part of God's plan and design for the fallen world. They also layout various strategies, reasons, and approaches for doing so. The richness of the breadth of authors brought together by the editors, O'Neill and Snodderly, in this volume makes it an opulent resource for thoughtful discussion and debate, whatever the reader's background. What emerges from the wealth of authors is that fighting disease requires more than physicians and medical personnel - it also requires other disciplines and specialists dealing with the physical, mental, social, and most importantly, the spiritual. The need is for scientists, researchers, public health practitioners, legal experts, community and social advocates, and spiritual leaders to work in an integrated manner to

Dec 2021. Christian Journal for Global Health 8(2) address taking God's creation back and working for it to be as God intended.

The book's central foundation is a vision of believers participating in helping the release of the world from disease, and the means by which God blesses the nations as he promised in Genesis that $\mathrm{He}$ would do through Abraham and his descendants. While the diversity of perspectives adds to the richness of the book, it also makes it a real challenge for the editors to be able thread a consistent unifying message of posits, arguments, and explanations. This is to be expected from a work with such varied and numerous authors representing multiple disciplines. Yet, it enriches the discussion and debate that ensues from wrestling with these issues.

This book, with its multiple perspectives and backgrounds of the various authors, contributes immensely to not only knowledge on the subject of disease and global health within a spiritual perspective, but to vigorous discussion and debate on evil as the source of disease and the myriad of root causes and varying approaches the church may undertake to address and ultimately eradicate disease, as God intends. The arguments presented, especially by O'Neill and Snodderly, in bringing together the various chapters, are clear and substantiated with solid and rigorous scholarly examination of the issues. One of the strengths of this publication is that it always integrates the spiritual element as an integral element in all of its explorations, rather than reverting to a strictly scientific perspective and then adding a spiritual angle at the end.

The reader of this book will be treated to a wide-ranging discussion of many approaches to developing a theology of disease in order to improve global health. It may be read from start to finish to gain a depth of understanding of the key issues in alleviating disease and promoting health to better understanding the church's range of the unique opportunities to address disease in a comprehensive manner. Alternatively, the reader may do a "pick and choose" of the chapters to address those issues about disease and global health that are of the 
greatest interest. The bottom line: this book makes a significant contribution to directing and redeploying the Christian global health community's focus on bringing healing and wholeness to the world: "We must also reveal by our actions his [God's] concerns for the conquest of evil and disease." ( $p$ 188).

Submitted 17 Oct 2021, accepted 27 Oct 2021, published 27 Dec 2021

Competing Interests: None declared.

Correspondence: William Newbrander, Pittsburgh, PA, USA. wcnewbrander@gmail.com

Cite this article as: Newbrander W. All Creation Groans: Toward a Theology of Disease and Global Health, edited by Daniel W. O'Neill and Beth Snodderly, Pickwick 2021. Christ J Global Health. Dec 2021; 8(2):41-44. https://doi.org/10.15566/cjgh.v8i2.589

(C) Author. This is an open-access article distributed under the terms of the Creative Commons Attribution License, which permits unrestricted use, distribution, and reproduction in any medium, provided the original author and source are properly cited. To view a copy of the license, visit http://creativecommons.org/licenses/by/4.0/ 